\title{
The clinical value of ficolin-3 gene polymorphism in rheumatic heart disease. An Egyptian adolescents study
}

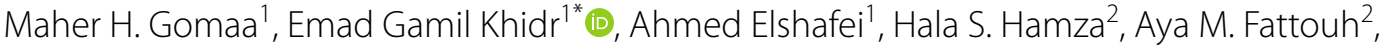 \\ Ahmed A. El-Husseiny ${ }^{1}$, Ahmed Aglan ${ }^{1}$ and Mahmoud Gomaa Eldeib ${ }^{1}$
}

\begin{abstract}
Objective: Ficolin-3 is one of the innate immunity molecules that was thought to play a pivotal role in Streptococcus pyogenes autoimmunity and its complications; rheumatic fever (RF) and rheumatic heart disease (RHD). We aimed to disclose if there is an association between ficolin-3 (FCN3) gene polymorphisms (rs4494157 and rs10794501) and RF with or without RHD for the first time in Egyptian adolescents.

Results: Serum ficolin-3 level was significantly elevated in patients suffering from RF with and without RHD in comparison with control. Regarding FCN3 gene (rs4494157) polymorphism, a significant correlation was found between the A allele and the susceptibility to RF with or without $\mathrm{RHD}(\mathrm{OR}=2.93, P=0.0002$ and $\mathrm{OR}=2.23, P=0.008$ respectively). Besides, $A A$ homozygous genotype showed a significant association with $\mathrm{RHD}$ risk $(\mathrm{OR}=3.47, P=0.026)$. Patients carrying the A allele (CA + AA) had significantly higher serum ficolin-3 than those carrying the CC genotype $\left(P^{<} 0.0001\right)$. While the frequency of ( $\mathrm{rs}$ 10794501) polymorphism revealed no significant differences between the controls and RF patients with or without $\mathrm{RHD}(\mathrm{OR}=1.43, P=0.261$ and $\mathrm{OR}=1.48, P=0.208$ respectively).
\end{abstract}

Keywords: Rheumatic fever, Rheumatic heart disease, FCN3 gene polymorphism, Ficolin-3

\section{Introduction}

Rheumatic fever (RF) is a consequence of recurrent group-A Streptococcus pyogenes (GAS) pharyngitis as an immune-mediated complication in genetically susceptible individuals $[1,2]$. Repeated or severe episodes of RF lead to permanent harm to the heart valves, with subsequent development of rheumatic heart disease (RHD). A high prevalence (31 per 1000 children) of RHD in schoolage children in Egypt and other African countries was reported [3].

Rheumatic fever and RHD are multifactorial disorders that involve multiple environmental and genetic

\footnotetext{
*Correspondence: emadgamil2003@azhar.edu.eg

${ }^{1}$ Department of Biochemistry and Molecular Biology, Faculty

of Pharmacy, Al-Azhar University, Cairo, Egypt

Full list of author information is available at the end of the article
}

factors [4]. The pathogenesis of RF and its sequel, particularly RHD is strongly dependent on autoimmunity. Autoantibodies produced from molecular mimicry between proteins of heart tissue and GAS mediate tissue damage. It was found that GAS molecules as $\mathrm{N}$-acetyl$\beta$-D-glucosamine (GlcNAc) and $\mathrm{M}$ protein display a cross-reactivity with valves and myocellular contractile proteins of the host. As one of the pathogen associated molecular patterns and a dominant antigen in GAS cell wall, GlcNAc serves as a target for identification by ficolins $[2,5-7]$.

Ficolins are group of patterns recognizing proteins that activate the complement system. Currently, they are classified into three types: ficolin-1 (M ficolin), ficolin-2 (L ficolin), and finally ficolin-3 (H ficolin) [7]. Ficolin-3 is mainly synthesized in both liver and lungs, representing the most abundant circulating ficolins [8]. Serum 
ficolin-3 has been reported to be widely variable among healthy individuals, which may be attributed to the difference in the genetic makeup [9-11]. Functionally, like other ficolins, ficolin-3 has been shown to activate the complement system $[12,13]$.

Ficolin-3 is encoded by the FCN3 gene which is located on chromosome $1 \mathrm{p} 36$ and contains eight exons. Few studies showed an association between ficolin genes polymorphisms and infectious and autoimmune diseases [14-19]. Additionally, it was reported that there are associations between gene polymorphisms of ficolin-1 [20] and ficolin-2 [21], 22 with RF. However, the impact of ficolin-3/FCN3 gene polymorphisms on RF and RHD is currently obscure.

Despite being a preventable disease, RHD may proceed silently until patients are presented as debilitating heart failure cases. In this case, surgery is the only possible choice for treatment [23], and deadly outcomes ultimately occur [24]. Indeed, there is a need for a predictive tool or a marker for early detection of RF/RHD and preventing their progression, as well as facilitating early medical follow-up.

This study was designed to investigate for the first time the association of two FCN3 gene polymorphisms (rs4494157 and rs10794501) as well as serum ficolin-3 levels with the susceptibility of RF and RHD development in Egyptian adolescents.

\section{Main text \\ Methods}

This study was performed on 240 Egyptian subjects locating in Cairo that were classified into three groups. The first group consisted of $80 \mathrm{RF}$ patients without RHD. The second group included 80 RF patients with RHD. While in the third group, eighty apparently healthy volunteers matching with the patients for age, sex, ethnic and geographic origin were selected as controls. The demographic data of individuals enrolled in the study were presented in Table 1 . RF patients were recruited from the Cardiology Outpatient Clinic, Children Hospital, Cairo University, Egypt. RF diagnosis was carried out based on the modified Jone's criteria
[25]. A free written informed consent form was signed by parents of both controls and patients. Approval of this study by the ethical committee of Children Hospital, School of Medicine, Cairo University, Egypt was obtained. Patients with any infections, acute RF, infective endocarditis, or any other inflammatory disorders were excluded from this study. All enrolled patients had a clinical history of RF. The presence of mitral valve regurge in patients with RHD was confirmed by an echocardiogram.

A venous blood sample was withdrawn from all subjects and divided into two aliquots; one for serum separation and determination of serum ficolin-3 levels by enzyme-linked immunosorbent assay (ELISA) using commercial kits (Ray Bio Kit Inc., Georgia, USA) based on manufacturer's instructions and recommendations, While the 2nd one for FCN3 gene polymorphisms (rs4494157 and rs10794501) typing (Additional file 1).

Extraction of Genomic DNA (gDNA) from the whole blood sample was performed using Gene JET $^{\mathrm{TM}}$ Whole Blood DNA Purification Mini Kit (Thermo Fisher Scientific Inc., USA). Polymorphisms at (rs4494157 and rs10794501) in the FCN3 gene were typed by realtime polymerase chain reaction (RT-PCR) utilizing TaqMan $^{\circledR}$ allele discrimination assay (Applied Biosystems, CA, USA).

GraphPad Prism 6.2 (GraphPad Software, San Diego, USA) was utilized to perform the statistical analysis of our data. Normality distribution of variables was checked using D'Agostino-Pearson Omnibus test, where normally distributed variables were presented as mean $\pm \mathrm{SE}$ while we used median (inter-quartile range) to represent the skewed distributed variables. Kruskal-Wallis test was used to compare between all groups followed by Dunn's test. Genotypes distribution for the polymorphism was checked for deviation from the Hardy-Weinberg equilibrium and any deviations between observed and expected frequencies were examined for detection of significance depending on the $X^{2}$ test. Besides, odds ratios (ORs) and 95\% confidence intervals (CIs) were calculated. A $P$-value $<0.05$ was considered statistically significant.

Table 1 Demographic data of all studied groups

\begin{tabular}{|c|c|c|c|c|}
\hline \multirow[t]{2}{*}{ Characteristics } & & \multirow[t]{2}{*}{ Controls $(\mathrm{n} .=80)$} & \multicolumn{2}{|l|}{$\operatorname{RF}(n .=160)$} \\
\hline & & & Without RHD (n. = 80) & With RHD (n. = 80) \\
\hline \multirow[t]{2}{*}{ Gender } & Female n. (\%) & $48(60.0)$ & $46(57.5)$ & $48(60.0)$ \\
\hline & Male n. (\%) & $32(40.0)$ & $34(42.5)$ & $32(40.0)$ \\
\hline $\begin{array}{l}\text { Age (years) mean } \pm S E \\
\text { Age range }\end{array}$ & & $\begin{array}{l}15.2 \pm 0.29 \\
13-20\end{array}$ & $\begin{array}{l}14.5 \pm 0.43 \\
9-18.5\end{array}$ & $\begin{array}{l}14.3 \pm 0.33 \\
9-18.5\end{array}$ \\
\hline
\end{tabular}




\section{Results}

The genotypic and allelic results of FCN3 single nucleotide polymorphism (SNP) (rs4494157) analysis for the studied groups were listed in Table 2. This genotype distribution showed no deviation from Hardy-Weinberg equilibrium $(P>0.05)$. The genotypic distribution revealed a higher frequency of the heterozygous CA only and CA/AA genotypes in RF patients with and without RHD when compared to controls. Moreover, the homozygous variant AA genotype showed higher frequency in RF with RHD as compared to controls. Additionally, a higher frequency of the A allele was observed in RF patients with and without RHD when compared to the controls.

The genotype distribution for FCN3 SNP (rs10794501) showed no deviation from Hardy-Weinberg equilibrium. No statistical significance was detected for the frequency of all genotypes and alleles among all groups, as enlisted in Table 2.

Serum ficolin-3 levels $(\mathrm{ng} / \mathrm{mL})$ were significantly increased in RF patients with and without RHD (18665 (1535-19640)) and (17965 (17420-19503)) respectively Vs controls (8490 (7695-8955)), while there was no significant difference between RF with and without RHD as shown by Fig. 1.

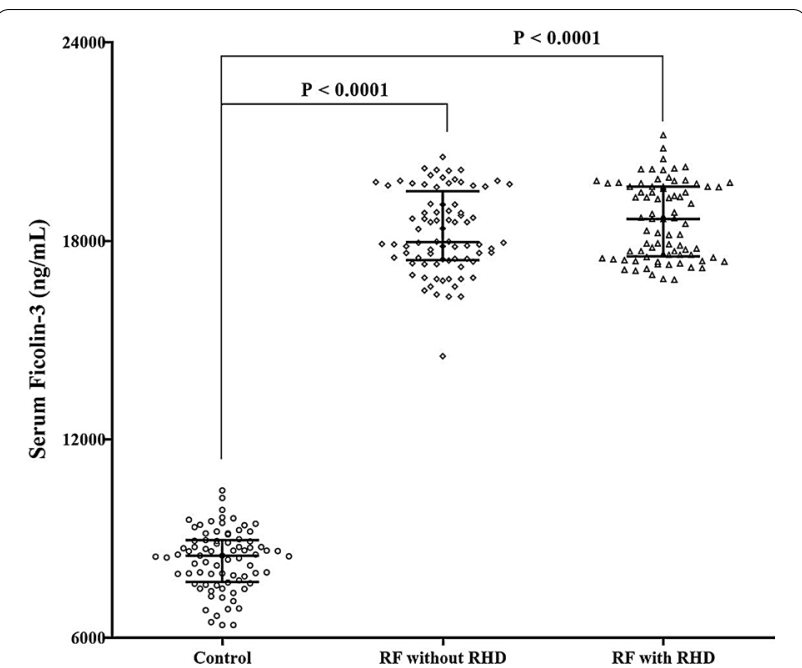

Fig. 1 Distribution of Ficolin-3 levels in the investigated groups. Comparisons were made using Kruskal-Wallis test followed by Dunn's test. Bars indicate median and interquartile values

On studying the differences in serum ficolin-3 levels according to the FCN3 (rs4494157) genotypes in all patients, results revealed that patients carrying the $\mathrm{A}$ allele $(\mathrm{CA}+\mathrm{AA})$ were associated with significantly higher serum ficolin-3 (Mean $\pm \mathrm{SE}=18941 \pm 128.6)$ than those

Table 2 Distribution of FCN3 genotypes (rs4494157 and rs10794501) in controls and patients with RF

\begin{tabular}{|c|c|c|c|c|c|}
\hline & Control n (\%) & RF without RHD n (\%) & RF with RHD n (\%) & OR $(95 \% \mathrm{Cl})$ & $P$ \\
\hline \multicolumn{6}{|c|}{ rs4494157 } \\
\hline \multicolumn{6}{|c|}{ Genotype distribution } \\
\hline CC & $64(80)$ & $49(61.25)$ & $43(53.75)$ & & \\
\hline CA & $10(12.5)$ & $20(25)$ & $23(28.75)$ & $\begin{array}{l}2.61(1.12-6.08)^{a} \\
3.42(1.48-7.91)^{b}\end{array}$ & $\begin{array}{l}0.026^{a^{*}} \\
0.005^{b^{*}}\end{array}$ \\
\hline $\mathrm{AA}$ & $6(7.5)$ & $11(13.75)$ & $14(17.5)$ & $3.47(1.24-9.74)^{b}$ & $0.026^{b^{*}}$ \\
\hline CA/AA & $16(20)$ & $31(38.75)$ & $37(46.25)$ & $\begin{array}{l}2.53(1.24-5.14)^{a} \\
3.44(1.70-6.95)^{b}\end{array}$ & $\begin{array}{l}0.016^{a^{*}} \\
0.0007^{b *}\end{array}$ \\
\hline \multicolumn{6}{|c|}{ Allele frequencies } \\
\hline C & $138(86.25)$ & $118(73.75)$ & 109 (68.12) & & \\
\hline A & $22(13.75)$ & $42(26.25)$ & $51(31.88)$ & $\begin{array}{l}2.23(1.26-3.95)^{a} \\
2.93(1.68-5.14)^{b}\end{array}$ & $\begin{array}{l}0.008^{a^{*}} \\
0.0002^{b^{*}}\end{array}$ \\
\hline \multicolumn{6}{|c|}{ rs10794501 } \\
\hline \multicolumn{6}{|c|}{ Genotype distribution } \\
\hline TT & $58(72.5)$ & $51(63.75)$ & $54(67.5)$ & & n.s \\
\hline $\mathrm{TA}$ & $17(21.25)$ & $21(26.25)$ & $16(20)$ & & \\
\hline AA & $5(6.25)$ & $8(10)$ & $10(12.5)$ & & \\
\hline TA/AA & $22(27.5)$ & $29(36.25)$ & $26(32.5)$ & & \\
\hline \multicolumn{6}{|c|}{ Allele frequencies } \\
\hline $\mathrm{T}$ & $133(83.1)$ & $123(76.9)$ & $124(77.5)$ & & n.s \\
\hline A & 27 (16.9) & $37(23.1)$ & $36(22.5)$ & & \\
\hline
\end{tabular}

$\mathrm{OR}$, odds ratio; $\mathrm{Cl}$, confidence intervals; $\mathrm{RF}$, rheumatic fever; $\mathrm{RHD}$, rheumatic heart disease; ${ }^{\mathrm{R} F}$ patients without $\mathrm{RHD}$ vs. control; ${ }^{\mathrm{b}} \mathrm{RF}$ patients with $\mathrm{RHD}$ vs. control; *Statistically significant different at $P<0.05$ using Fisher exact test, n.s., non-significance 
carrying the CC genotype $(18059 \pm 119.2), P^{<} 0.0001$. However, the classification of the RF group according to the FCN3 (rs10794501) genotypes showed no significant differences regarding serum ficolin-3 level between TT $(18555 \pm 115)$ and TA + AA genotypes $(18203 \pm 159.7)$, $P=0.111$. Thus, no association between ficolin-3 and FCN3 gene polymorphism (rs10794501) was detected.

\section{Discussion}

Few genetic polymorphisms in the innate proteins that participate in the immune responses have been implicated in RF and RHD vulnerability [26]. Unfortunately, studies on the significance of ficolins in RF and RHD are insufficient, despite their obvious contribution in the activation of the innate immune response through complements and in autoimmunity [27]. Few previous studies on FCN1 and FCN2 genes have determined that some polymorphisms of both genes could give a protective role against RF, by empowering bacterial elimination in addition to activation of the expression of these genes leading to an increase in the production of their proteins [20-22].

Up till now, the role of FCN3 gene polymorphisms in RF and RHD pathogenesis remains unknown. As far as we could possibly know, this is the first study to investigate FCN3 gene polymorphisms (rs4494157 and rs10794501) together with their related genotypes and levels of serum ficolin-3 in patients suffering from RF and RHD.

In the current study, the significant higher serum level of ficolin-3 in RF patients with and without RHD than the control subjects reflects its role in complements initiation and subsequent pathogenesis of RF and RHD. There have been no reports concerning the relationship between ficolin-3 and RF but several findings are indicating that high levels of ficolin-3 may contribute to the induction of inflammation as in diabetic retinopathy [28], leprosy [29], ovarian cancer [30], acute leukemia [31] and associated with post-operative graft loss in kidney transplantation [32].

Based on the inflammatory progression associated with high levels of ficolin-3, it was assumed that the involvement of ficolin-3 in immune evasion of Streptococcus pyogenes in RF and RHD patients is a result of its antiopsonic response to complements overactivation [33].

Interestingly, lectin pathway activators, including mannose-binding lectin (MBL), both ficolin-1 and ficolin-2 were appeared to bind to Streptococcus pyogenes leading to MBL associated serine proteases activation [34]. Although, no direct binding of ficolin-3 on Streptococcus pyogenes was found, it is known that the Streptococcus pyogenes cell wall contains long polymers of ficolins target; GlcNAc [35] and hence could be a potential ligand for ficolin-3. Therefore, our findings open a new window to study the potential interaction between ficolin-3 and Streptococcus pyogenes.

Ficolins are group of proteins with different pattern in tissue expression as well as their immunological roles. The reason beyond the decline in ficolin- 1 and ficolin-2 levels in RF patients like what was found in other studies [20-22] may be a result of their consumption on the surface of GAS, in addition to the possibility of transcriptional mutations in their genes that may affect their levels.

As the most abundant ficolins in plasma [8], ficolin-3 level was more elevated even after being utilized in immune reactions against GAS, besides the possible effect of our studied SNPs on its expression. In addition to, the compensatory mechanisms of up-regulation of this protein that resulted from its interaction with GlcNAc as well as complement activation.

Given the (rs4494157), we observed that higher ficolin-3 levels were also associated with certain genotypes of FCN3 that contain the A allele in intron 7. Interestingly, intron 7 contains $\mathrm{CpG}$ islands and enriched for typical modifications of histone that are known to characterize active enhancers [36, 37].

The most important result in this study was related to the FCN3 A allele (rs4494157). Our finding suggests that this allele may be a risk factor for the progression of RF to its chronic consequences. Thus, FCN3 A allele carrying patients may be at high risk for recurrent infection, and a higher likelihood to develop RHD. Consequently, early identification, careful monitoring should be given for those patients. Furthermore, clinicians must confirm adherence of those patients to secondary prophylaxis intervention [38]. In fact, secondary prophylaxis adherence of RF patients is typically poor, especially in young people which was perceived as the principal explanation for RF repeats and RHD advancement $[38,39]$.

What is more, the presence of the $\mathrm{C}$ allele in controls in a higher significant pattern than RF patients could show that the presence of the $C$ allele may pose a defensive action against the occurrence of RF and RHD. Moreover, these data propose that the cardiac manifestations development of RF is related to high ficolin-3 levels and its linked genotypes, also, this relationship is a direct result of a certain mechanism related to FCN3 gene polymorphism but not secondary to the acute phase of GAS infection. This mechanism may involve the recognition of structures on damaged/altered cardiac cells by ficolin-3 that mediates complement activation and increases tissue injury, which may become permanent in the cardiac valves. 


\section{Conclusion}

This study suggests that the variant A allele of $F C N 3$ (rs4494157) is associated with high serum ficolin-3 levels, and the susceptibility to RF and RHD indicating a need for echocardiographic screening, and prophylactic intervention to prevent the disease burden, especially in resources constrained nations.

\section{Limitations}

SNPs selection was dependent on what we have found in the literature. However, there are many SNPs that could be highly prominent in ethnics included in this study.

The sample size was not huge enough to clarify a more extensive picture for FCN3 genotype distribution among Egyptian adolescents. So, to verify these findings, further larger sample-based studies are recommended in Egyptians and Mediterranean ethnics.

\section{Supplementary Information}

The online version contains supplementary material available at https://doi. org/10.1186/s13104-021-05450-w.

Additional file 1. ELISA kit methodology and genetic techniques details.

\section{Acknowledgements}

Deepest gratitude to the managerial and nursing team of Children Hospital, Cairo University, Egypt who made our patients'identification and sampling easy and to accomplish this work. Thanks to the staff of Biochemistry and Molecular Biology Department, Faculty of Pharmacy, Al-Azhar University, Cairo, who enabled us to utilize the central lab facilities to accomplish the practical work

\section{Authors' contributions}

$\mathrm{HSH}$ and AMF were responsible for patients' diagnosis, clinical recruitment and sampling. MGE, AE, and EGK carried out the practical part of the work. $\mathrm{AAE}$ and $\mathrm{AA}$ contributed in statistical analysis and data collection. MHG, AE, and MGE contributed equally in literature collection, manuscript writing, and thorough reviewing. All authors read and approved the final manuscript.

\section{Funding}

This work was totally a self-funded research by the authors, without financial support from any organization.

\section{Availability of data and materials}

The datasets generated and/or analysed during the current study are available in the ClinVar repository, Accession numbers SCV001468298-SCV001468299.

\section{Ethics approval and consent to participate}

This study has been approved by the ethical committee of Children Hospital, School of Medicine, Cairo University, Egypt. A free written informed consent form was signed by parents of both controls and patients.

\section{Consent for publication}

Not applicable.

\section{Competing interests}

The authors declare that they have no competing interests.

\section{Author details}

${ }^{1}$ Department of Biochemistry and Molecular Biology, Faculty of Pharmacy, AlAzhar University, Cairo, Egypt. ${ }^{2}$ Department of Pediatrics, Kasr Al-Ainy School of Medicine, Cairo University, Cairo, Egypt.

Received: 21 August 2020 Accepted: 12 January 2021

Published online: 26 January 2021

\section{References}

1. Steer AC. Historical aspects of rheumatic fever. J Paediatr Child Health. 2015;51(1):21-7.

2. Guilherme L, Kalil J. Rheumatic heart disease: molecules involved in valve tissue inflammation leading to the autoimmune process and anti-S. pyogenes vaccine. Front Immunol. 2013;4:352.

3. Kotit S, Said K, ElFaramawy A, Mahmoud H, Phillips DI, Yacoub MH. Prevalence and prognostic value of echocardiographic screening for rheumatic heart disease. Open heart. 2017;4(2):e000702.

4. Tian C, Hromatka BS, Kiefer AK, Eriksson N, Noble SM, Tung JY, Hinds DA. Genome-wide association and HLA region fine-mapping studies identify susceptibility loci for multiple common infections. Nat Commun. 2017;8(1):599.

5. Zühlke LJ, Beaton A, Engel ME, Hugo-Hamman CT, Karthikeyan G, Katzenellenbogen JM, Ntusi N, Ralph AP, Saxena A, Smeesters PR. Group A streptococcus, acute rheumatic fever and rheumatic heart disease: epidemiology and clinical considerations. Curr Treatment Options Cardiovas Med. 2017;19(2):15.

6. Matsushita M. Ficolins in complement activation. Mol Immunol. 2013;55(1):22-6.

7. Garred P, Honoré C, Ma YJ, Rørvig S, Cowland J, Borregaard N, Hummelshøj T. The genetics of ficolins. J Innate Immunity. 2010;2(1):3-16.

8. Tizzot MR, Lidani KCF, Andrade FA, Mendes HW, Beltrame MH, Reiche $\mathrm{E}$, Thiel S, Jensenius JC, de Messias-Reason IJ. Ficolin-1 and Ficolin-3 plasma levels are altered in HIV and HIV/HCV Coinfected patients from Southern Brazil. Front Immunol. 2018;9:2292.

9. Hummelshoj T, Munthe-Fog L, Madsen HO, Fujita T, Matsushita M, Garred P. Polymorphisms in the FCN2 gene determine serum variation and function of Ficolin-2. Hum Mol Genet. 2005;14(12):1651-8.

10. Yae Y, Inaba S, Sato H, Okochi K, Tokunaga F, Iwanaga S. Isolation and characterization of a thermolabile $\beta-2$ macroglycoprotein ('thermolabile substance'or 'Hakata antigen') detected by precipitating (auto) antibody in sera of patients with systemic lupus erythematosus. Biochimica et Biophysica Acta (BBA) Protein Struct Mol Enzymol. 1991;1078(3):369-76.

11. Munthe-Fog L, Hummelshøj T, Ma YJ, Hansen BE, Koch C, Madsen HO, Skjødt K, Garred P. Characterization of a polymorphism in the coding sequence of FCN3 resulting in a Ficolin-3 (Hakata antigen) deficiency state. Mol Immunol. 2008;45(9):2660-6.

12. Matsushita M, Endo Y, Fujita T. Cutting edge: complement-activating complex of ficolin and mannose-binding lectin-associated serine protease. J Immunol. 2000;164(5):2281-4.

13. Matsushita M, Kuraya M, Hamasaki N, Tsujimura M, Shiraki H, Fujita T. Activation of the lectin complement pathway by $\mathrm{H}$-ficolin (Hakata antigen). J Immunol. 2002;168(7):3502-6.

14. Ammitzbø\| CG, Kjær TR, Steffensen R, Stengaard-Pedersen $K$, Nielsen HJ, Thiel S, Bøgsted M, Jensenius JC. Non-synonymous polymorphisms in the FCN1 gene determine ligand-binding ability and serum levels of M-ficolin. PLOS ONE. 2012;7(11):e50585.

15. Kasperkiewicz K, Eppa Ł, Świerzko AS, Bartłomiejczyk MA, Żuber ZM, Siniewicz-Luzeńczyk K, Mężyk E, Matsushita M, Bąk-Romaniszyn L, Zeman K. Lectin pathway factors in patients suffering from juvenile idiopathic arthritis. Immunol Cell Biol. 2017:95(8):666-75.

16. Addobbati C, de Azevedo SJ, Tavares NA, Monticielo O, Xavier RM, Brenol JC, Crovella S, Chies JA, Sandrin-Garcia P. Ficolin gene polymorphisms in systemic lupus erythematosus and rheumatoid arthritis. Ann Hum Genet. 2016;80(1):1-6.

17. Boldt AB, Sanchez MIN, Stahlke ER, Steffensen R, Thiel S, Jensenius JC, Prevedello FC, Mira MT, Kun JF, Messias-Reason IJ. Susceptibility to leprosy is associated with M-ficolin polymorphisms. J Clin Immunol. 2013;33(1):210-9. 
18. Haerynck F, Van Steen K, Cattaert T, Loeys B, Schelstraete P, Claes K, Van Thielen M, De Canck I, John JM, De Baets F. Polymorphisms in the lectin pathway genes as a possible cause of early chronic Pseudomonas aeruginosa colonization in cystic fibrosis patients. Hum Immunol. 2012;73(11):1175-83.

19. Vander Cruyssen B, Nuytinck L, Boullart L, Elewaut D, Waegeman W, Van Thielen M, De Meester E, Lebeer K, Rossau R, De Keyser F. Polymorphisms in the ficolin 1 gene (FCN1) are associated with susceptibility to the development of rheumatoid arthritis. Rheumatology. 2007;46(12):1792-5.

20. Catarino SJ, Andrade FA, Boldt ABW, Guilherme L, Messias-Reason IJ. Sickening or healing the heart? The association of Ficolin-1 and Rheumatic Fever. Front Immunol. 2018;9:3009.

21. Messias-Reason I, Schafranski M, Kremsner P, Kun J. Ficolin 2 (FCN2) functional polymorphisms and the risk of rheumatic fever and rheumatic heart disease. Clin Exp Immunol. 2009;157(3):395-9.

22. Elshamaa MF, Hamza H, El Rahman NA, Emam S, Elghoroury EA, Farid TM, Zaher AZ, Ibrahim MH, Kamel S, El-Aziz DA. Association of ficolin-2 (FCN2) functional polymorphisms and protein levels with rheumatic fever and rheumatic heart disease: relationship with cardiac function. Arch Medi Sci Atherosclerotic Dis. 2018:3:e142.

23. Nishimura RA, Otto CM, Bonow RO, Carabello BA, Erwin JP, Guyton RA, O'Gara PT, Ruiz CE, Skubas NJ, Sorajja P. 2014 AHA/ACC guideline for the management of patients with valvular heart disease: a report of the American College of Cardiology/American Heart Association Task Force on Practice Guidelines. J Am Coll Cardiol. 2014;63(22):e57-185.

24. Watkins DA, Johnson CO, Colquhoun SM, Karthikeyan G, Beaton A, Bukhman G, Forouzanfar MH, Longenecker CT, Mayosi BM, Mensah GA. Global, regional, and national burden of rheumatic heart disease, 1990-2015. N Engl J Med. 2017;377(8):713-22.

25. Gewitz MH, Baltimore RS, Tani LY, Sable CA, Shulman ST, Carapetis J, Remenyi B, Taubert KA, Bolger AF, Beerman L. Revision of the Jones Criteria for the diagnosis of acute rheumatic fever in the era of Doppler echocardiography: a scientific statement from the American Heart Association. Circulation. 2015;131(20):1806-18.

26. Guilherme L, Köhler K, Kalil J. Rheumatic heart disease: genes, inflammation and autoimmunity. Rheumatol Curr Res doi. 2012;10(4172):2161-1149

27. Howard M, Farrar CA, Sacks SH: Structural and functional diversity of collectins and ficolins and their relationship to disease. Seminars in immunopathology. Springer; 2018, pp. 75-85.

28. Zheng B, Li T, Chen H, Xu X, Zheng Z. Correlation between ficolin-3 and vascular endothelial growth factor-to-pigment epithelium-derived factor ratio in the vitreous of eyes with proliferative diabetic retinopathy. Am J Ophthalmol. 2011;152(6):1039-43.

29. Andrade FA, Beltrame MH, Bini VB, Gonçalves LB, Boldt ABW, de MessiasReason IJ. Association of a new FCN3 haplotype with high ficolin-3 levels in leprosy. PLoS neglected tropical diseases. 2017;11(2):e0005409.

30. Szala A, Sawicki S, Swierzko AS, Szemraj J, Sniadecki M, Michalski M, Kaluzynski A, Lukasiewicz J, Maciejewska A, Wydra D. Ficolin-2 and ficolin-3 in women with malignant and benign ovarian tumours. Cancer Immunol Immunother. 2013:62(8):1411-9.

31. Schlapbach LJ, Aebi C, Hansen A, Hirt A, Jensenius J, Ammann R. H-ficolin serum concentration and susceptibility to fever and neutropenia in paediatric cancer patients. Clin Exp Immunol. 2009;157(1):83-9.

32. Smedbråten YV, Sagedal S, Mjøen G, Hartmann A, Fagerland MW, Rollag $\mathrm{H}$, Mollnes TE, Thiel S. High ficolin-3 level at the time of transplantation is an independent risk factor for graft loss in kidney transplant recipients. Transplantation. 2015;99(4):791-6.

33. Molinari G, Chhatwal GS. Streptococcal invasion. Curr Opin Microbiol. 1999:2(1):56-61.

34. Beltrame MH, Catarino SJ, Goeldner I, Boldt ABW, de Messias-Reason IJ. The lectin pathway of complement and rheumatic heart disease. Front Pediatrics. 2015;2:148

35. Runza VL, Schwaeble W, Männel DN. Ficolins: novel pattern recognition molecules of the innate immune response. Immunobiology. 2008:213(3-4):297-306.

36. Deaton AM, Bird A. CpG islands and the regulation of transcription. Genes Dev. 2011;25(10):1010-22.

37. Shlyueva D, Stampfel G, Stark A. Transcriptional enhancers: from properties to genome-wide predictions. Nat Rev Genet. 2014;15(4):272-86.

38. Marzetti V, Di Battista C, Ferrante R, Carlucci L, Balsamo M, Stuppia L, Lapergola G, Antonucci I, Chiarelli F, Breda L. MBL2 and FCN2 gene polymorphisms in a cohort of Italian children with rheumatic fever: a case-control study. Seminars in arthritis and rheumatism. Elsevier. 2017; pp. 264-268.

39. Pelajo CF, Lopez-Benitez JM, Torres JM, de Oliveira SK. Adherence to secondary prophylaxis and disease recurrence in 536 Brazilian children with rheumatic fever. Pediatric Rheumatol. 2010;8(1):22.

\section{Publisher's Note}

Springer Nature remains neutral with regard to jurisdictional claims in published maps and institutional affiliations.
Ready to submit your research? Choose BMC and benefit from:

- fast, convenient online submission

- thorough peer review by experienced researchers in your field

- rapid publication on acceptance

- support for research data, including large and complex data types

- gold Open Access which fosters wider collaboration and increased citations

- maximum visibility for your research: over $100 \mathrm{M}$ website views per year

At BMC, research is always in progress.

Learn more biomedcentral.com/submissions 